\title{
An Extra-European Reader's Rereading of The Professor
}

\section{Mst. Sharmin Sultana}

Lecturer, Department of English, Jashore University of Science and Technology, Bangladesh

\begin{abstract}
Nineteenth century English novel and the British colonial history share a very special relationship. Though mostly the novels of this period played an important role in constructing the ideology that helped the process of imperialism start and retain, the interaction among different agencies regarding colonial project in any particular novel is very complicated. The paper seeks to re-read the first written but posthumously published novel by Charlotte Bronte, The Professor. Though on the surface The Professor seems to be an innocent love story, a contrapuntal reading unveils the apparent or latent references to colonialism in it. Though in this novel imperial power Belgium plays a great role, direct or indirect references to British colonies are also there. In fact the exploration of Belgian Colonial power seems to be an oblique mode of dealing with British Empire. Rereading The Professor with an awareness of colonial history can be helpful in the understanding of the subtle hegemonic working of the neo-colonisation of the present time.
\end{abstract}

Keywords-Belgium, Colonialism, England, Language, Novel.

An empire cannot stand and continue solely on administrative grounds; it needs an ideology to work simultaneously through the complicated web of culture. Through Orientalism the ideology of binary oppositions is created in the human consciousness in which all positive qualities are attributed to the West while all negative ones are assigned to the East. It is not the East or the Orient only that undergoes the process of Orientalisation but the same process is employed for all the parts of the world which happened to be the colonies of the "great" Empires. These ideologies not only offer the West with an opportunity to give their economically driven imperial project the label of a "holy duty" to civilise the dark parts of the world, they also have an insidious effect on the psychology of the colonised population who gradually come to believe that they are inferior and need the help of West to progress. Art and literature as cultural products have always been the embodiment of ideologies. Colonial literatures, especially the novels are an important part of the discourse of colonialism and colonisation which "obscures the underlying political and material aims of colonization" (Edward Said 15). Novels are primarily works of art but Edward Said in his book The World, the Text and the Critic opines that it is important to remember that art and literature are born in this world and therefore, novels like any form of knowledge are never apolitical. So, trying to read a colonial novel keeping the imperial history in mind is just an attempt to add a historical and political dimension to the existing readings of that work. Said in his book, Culture and Imperialism suggests contrapuntal mode of reading and reading a colonial text contrapuntally means reading it "with a simultaneous awareness both of the metropolitan history that is narrated and of those other histories against which (and together with which) the dominating discourse acts" (Culture and Imperialism 59) Contrapuntal reading unveils the narrative's structural and thematic connection with colonisation. Direct or indirect references and sometimes no references to the process of colonization in the novels of nineteenth century Britain play important role in forwarding the colonial agenda, creating colonialist ideology, making it normal and even rarely questioning it.

It is not only the colonised nations or ethnicities that suffer a negative projection in The Professor by Charlotte Bronte but also other colonial powers in competition with England become subject to an unfair representation. When one tries to read the novel contrapuntally the novel's structural and thematic relation with the imperial project gets revealed. The society in England presented in the narrative with its 
economy that supports its particular life-style and moral standard is mostly dependent on the wealth coming from the far-off colonies. Even the careers of most of the characters including the protagonist of The Professor are oriented in different imperial powers whether Britain or Belgium. The novel starts with a letter that the narrator, protagonist William Crimsworth writes to his friend, Charles. After the letter the narrator informs that his friend never got the letter as he "had accepted a Government appointment in one of the colonies, and was already on his way to the scene of his official labours" (The Professor 15).

William proudly declares in his letter to his friend that he is "no Oriental" and so white necks, carmine lips and cheeks will not suffice for him instead of intellect (15). Mr. Hunsden also gives a negative picture of the orient when he tells William that the patrician descent women cultivate beauty just like the "oriental odalisques" (25) as if the history of a king's concubines is something particular with the orient.

When William reaches Belgium he accepts the place to be beautiful but still he longs for the "small and dingy, though not uncomfortable" (47) apartment back in London. He recalls his London days, the St. Paul's great bell, and the dome with a strong and passionate sense of love for his country. He utters, "I suppose the sensations, stirred by those first sounds, first sights, are felt but once; treasure them, Memory; seal them in urns, and keep them in safe niches!" (48). Patriotism comes closer to the intensity of religion when Frances Evans Henri tells him that she will go and live in England and teach French there and Williams finds the word "England" pronounced as emphatically as "an Israelite of Moses' days would have said Canaan" (113). But often this passionate feeling for homeland comes to the verge of being snobbish and sometimes, aggressive nationalism. William shares his disgust for the Flemish, especially by the way they butcher the English language when he attempts to teach them. A Flemish housemaid is reported to be "not pretty or polite" but "picturesque" (48). Though at the beginning French in the mouths of Frenchmen or Belgians feels like "music" to the ears of the narrator, soon Belgian accent turns into "horrors" to him. William's English nationality seems to attribute him with the right to judge individuals of other nations or ethnicities and most importantly, almost all the positive or negative qualities in any human being are not counted as personal rather they are always mentioned with connection to his or her country of origin and thus they become the national traits. William describes the youth of Brabant with a strong sense of superiority.

Their intellectual faculties were generally weak, their animal propensities strong; thus there was at once an impotence and a kind of inert force in their natures; they were dull, but they were also singularly stubborn, heavy as lead and, like lead, most difficult to move. Such being the case, it would have been truly absurd to exact from them much in the way of mental exertion; having short memories, dense intelligence, feeble reflective powers, they recoiled with repugnance from any occupation that demanded close study or deep thought. Had the abhorred effort been extorted from them by injudicious and arbitrary measures on the part of the Professor, they would have resisted as obstinately, as clamorously, as desperate swine; and though not brave singly, they were relentless acting en masse. (The Professor 55)

In the girls' school, too, William describes the girls in a quite negative light. According to him they are selfish, ignorant liars with audacity and low mental capacity. He gives an account of his experience with one of his students, Juanna Trista. She is reported to make "noises with her mouth like a horse," eject her saliva and utter "brutal expressions." The narrator goes on describing, "behind and below her were seated a band of very vulgar, inferior-looking Flamandes, including two or three examples of that deformity of person and imbecility of intellect whose frequency in the Low Countries would seem to furnish proof that the climate is such as to induce degeneracy of the human mind and body" (81). The British girls in the school are said to be clean with erect carriage, flexible figures, white and taper hands. Besides, Williams is happy to tell the readers that they are "more intellectual than those of the Belgians" with a "grave and modest countenance" and a "general air of native propriety and decency" (82). This type of narrative forwards the idea of some nations or ethnicities being naturally inferior and thus their being deserving to be ruled and corrected by the "superior" nations.

Once, the protagonist of the novel sympathises with the two badly treated Flamand ushers in the establishment but even in his recognition of their being good human beings there is a bearing of generosity from the superior and also, he does not fail to mention their weakness (in his judgment). He says, "Flamands certainly they were, and both had the true Flamand physiognomy, where intellectual inferiority is 
marked in lines none can mistake; still they were men, and, in the main, honest men; and I could not see why their being aboriginals of the flat, dull soil should serve as a pretext for treating them with perpetual severity and contempt" (56). Even, while the English protagonist admires his French Headmaster for his intelligence, he never fails to articulate English supremacy by accusing him of "a degree of laxity in his code of morals" (56) and claiming himself to abhor mere licentiousness. William describes the Headmaster's mother as ugly "as only continental old women can be" (57) and he even, doubts her intention in the invitation to tea as an amorous project. He thinks that the Belgian old women permit themselves "a licence of manners, speech, and aspect," such as English "venerable granddames would recoil from as absolutely disreputable" (59). Being a through Frenchman Pelet is said to have the national characteristic of ferocity, fiendish nature and flashes of fierceness. Moreover, the narrator says that Pelet's bachelor's life has been passed in "proper French style with due disregard to moral restraint" and his married life is also promised to be very French (145146). In chapter XXIV there is a long argumentative conversation mostly between Frances and Hunsden on countries, nations, their greatness, patriotism and so on. Though Hunsden accuses England of august aristocracy, excessive concern for fashion, corruption, he also talks about its achievements in scientific discovery, enterprise and industry. On the other hand, Frances opines that every country has problems but England is "the most glorious region [she] can conceive" (185-186). Her passion for England and Switzerland has a certain degree of religious zeal in it. In the narrative nationalism and patriotism come very close to the place of religion as it is said that "England [is] still her Promised Land" (194). Even when Hunsden says that he is "a universal patriot", Frances answers, "sympathies so widely diffused must be very shallow" (188).

In nineteenth century for colonizing the minds in the European colonies a Euro-centric educational system had to be established first. Controlling the education system has always been a very important tool of colonisation. The main plot of The Professor is centred on an educational system where the colonizers are the tutors and play the upper-hand master in possession of knowledge and authority in a hierarchical establishment. Even the half-English pupil-tutor Frances Evans Henri is tutored by the full-English hero William Crimsworth. While William shares his experience with foreign students in Belgium the whole educational project echoes the process of colonisation. Williams, who has already meticulously studied the characters of his new students, progresses very carefully with a certain scheme to handle the unruly rebellious students. He begins with "gentle, considerate" gesture and after reaching a certain point fixes his foot and "plant[s] it, root[s]it in rock," becomes "immutable as the towers of Ste. Gudule" and finally expects the "Flemish gratitude and magnanimity in showers of Brabant saliva and handfuls of Low Country mud." Now "the most tolerant of masters" can change into a "despot" at a single word of impertinence or "a movement of disobedience" who offers only "one alternative - submission and acknowledgment of error, or ignominious expulsion" (55). Firdous Azim opines that "the pedagogical enterprise is central" in this novel and the power relations between the English teacher and the non-English students are "translated into sexual terms, as a male professor teaches female students" (The Colonial Rise of the Novel 149).

One can easily notice that learning languages and literature occupies an important place in the narrative. Languages of the colonial powers like English or French are crossing borders containing the world-view and philosophy of the mother countries and finding new foreign mouths to be uttered. The protagonist is presented with a certain obsession with English language, accuracy of its pronunciation or grammar, its beauty, its sounds and of course the way of life it represents. William's disgust at the faulty English pronunciation can be seen as his getting disturbed by the disrupting presence of "the Other." Moreover, Frances Evans Henri is said to derive "both pleasure and profit from the study of her mother-tongue" (The Professor 117). Suggesting the superiority of English literature and hinting at the popular but immoral romantic plots of the modern French novels William proudly declares that they "are not to [his] taste, either practically or theoretically" (147).

In imperial ideology the mother country is the home of perfect virtues and all other lands have a corrupting and polluting effect and this particular idea is reflected in William's opinion that the continental English girls in the establishment are poor creatures who have never known the "advantages of settled homes" and "honest Protestant education" rather they have picked up "some scanty instruction, many bad habits," lost every notion even of the first elements of religion and morals and acquired "an imbecile indifference to every sentiment that can elevate humanity" while they have been moving with their parents from one country to another (82). 
In most of Charlotte Bronte's works like Jane Eyre and Shirley the relationship between the coloniser and the colonised is paralleled with that between a man and a woman. The mastery, power and authority in these relationships are often explored with curiosity in the novels by Bronte. In The Professor, too, the hero is an English man while the heroine is only half-English. Championing English language, ways and identity over others, the hero educates the half-English heroine, Frances in his language, principles and way of life and only after ensuring her essential Englishness, he marries her. Even after their marriage he remains "the master in all things" (197). But traces of resistance are also there as Frances Henri potentially remains a rebellious character. The strong and determined voice of Frances against male domination sounds very similar to one against national or ethnic domination. With "a strange kind of spirit" in her eyes Frances eloquently declares:

[I]f a wife's nature loathes that of the man she is wedded to, marriage must be slavery. Against slavery all right thinkers revolt, and though torture be the price of resistance, torture must be dared: though the only road to freedom lie through the gates of death, those gates must be passed; for freedom is indispensable (The Professor 199).

In the narrative the parallelism between oppressed ethnic or racial identity and oppressed gender identity comes to the foreground when Frances suggests that if Mr. Hunsden marries a Swiss woman and keeps on blaspheming Helvetia and cursing the cantons, some night she "smother her Breton-bretonnant, even as [his] own Shakespeare's Othello smothered Desdemona" (189).

In the graveyard scene in a moment of reflection William accepts the fact that "every nation, tribe and kindred, mourned after its own fashion; and how soundless [is] the mourning of all" (131). But this sympathetic view of universal humanity soon gets faded by the feeling of aggressive nationalism in the narrative which is a very important element in the whole process of colonizing different nations.

In the age of colonization the colonisers needed to construct an identity for the colonised as their "deepest and most recurring images of the Other" (Orientalism 1) which is inferior and therefore, legitimised their act of intrusion. In this process of "Othering" or Orientalism the novels of the age played a significant role. But after all, novels are works of art and the workings of ideologies in them have never been so simple. The Western identity is ingeniously constructed over centuries with East as its inferior Other. It seems that the protagonist in The Professor, William Crimsworth is placed in the polyglot and cosmopolitan atmosphere of Belgium "to examine the primacy of his mother tongue" (The Colonial Rise 148) and the cultural supremacy of his motherland not only over the cultures of the colonies but also over that of France and Belgium, the other imperial powers. While most of the time the author seems to feel pride in British nationalism and its "Great Empire" which is very natural as Bronte shares the British identity with her other countrymen, some lines in the novel clearly raises questions regarding slavery or oppression in relation to colonisation. In the present time when the relation between culture and imperialism, involving identity politics and right of representation, has become very subtle and hegemonic in nature, contrapuntal reading of canonical texts can help us to understand the complexity of this relation. For, the ultimate job of an intellectual is "not to advance complex specialised 'theologies' but to "speak truth to power" (Edward Said 37)

\section{REFERENCES}

[1] Azim, Firdous. (2002). The colonial Rise of the Novel. Taylor \& Francis e-Library. Web. 14 May 2016.

[2] Ashcroft, Bill and Ahluwalia, Pal. (2008). Edward Said. $2^{\text {nd }}$ ed. Taylor \& Francis e-Library. Web. 16 Jul. 2016.

[3] Bronte, Charlotte. (2007). Shirley. London: Oxford University Press. Print.

[4] - - . (2010). The Professor. London: Arcturus. Print.

[5] - - - (1909). Villette. New York: Dent. Print.

[6] Said, Edward W. (1994). Culture and Imperialism. London: Vintage. Print.

[7] - - . (1991). Orientalism. Haryana: Penguin. Print.

[8] - - . (1983). The World, the Text and the Critic. Cambridge, Massachusetts: Harvard University Press. Print. 